\title{
Dünyada ve Türkiye'de Anlam İnşasının Aracı Olarak Sanat ve Edebiyat Basını
}

\author{
Art and Literature Press as the Tool of Meaning Construction in the World and Turkey
}

Bahar Kayıhan, Dr. Öğr. Üyesi, Ankara Hacı Bayram Veli Üniversitesi İletişim Fakültesi, E-posta: bahar.kayihan@hbv.edu.tr

https://doi.org/10.47998/ikad.747291

Anahtar Kelimeler:

Basın Tarihi, Edebiyat Basın1, Sanat, Sanat Basinı, Sanat Dergileri.

\section{Keywords:}

Press History, Literature Press, Art, Art Press, Art Magazines.

\section{$\ddot{O} z$}

Tarih boyunca basın, edebiyatın ve sanatın hem öznesi hem de nesnesi olmuştur. Bu çalışmada, 17. Yüzyıldan günümüze kadar dünyadaki, Osmanlı'daki ve sonrasında Türkiye'deki sanat ve edebiyat basınının toplumsal dönüşümler açısından nasıl bir rol oynadığı ve nasıl bir dönüşüm geçirdiği incelenmiştir. Ekonomi-politik yapıda dönüşümler gerçekleştikçe, sanayileşme ile birlikte meta haline gelen sanat ürünlerinin de değiştiği, sanat değiştikçe basının da hem içerik, hem biçim, hem de oynadığı rol anlamında farklılaştığı görülmüştür. Aydınlanma, sanayileşme, Fransız Devrimi, 1848 Devrimleri, Büyük Buhran, savaş gibi dönemler, sanat basınını dönüştürmüş̧ür. Aydınlanma ile birlikte isyan ve şiddetin yerini edebiyat ve sanat almıştır. Özgürlük arayışlarının ortaya çıktığı 19. Yüzyılda dergiler ve gazeteler de bu arayışı bir parçası haline gelmiştir. Savaş dönemlerinde ise sanat ve edebiyat basını hem bir propaganda aracı olarak kullanılmıştır, hem de savaş karşı1tı görüşleri yansıtmıştır. Yalnızca savaş dönemlerinde değil, hemen her dönemde sanat basını politik görüşlerin bir aktarıcısı olmuştur. 20. yüzyıl sanatın teknoloji ile buluşmasına tanık olmuştur. 1970'lerden sonra dijital teknolojilerin hızla gelişimi ile birlikte, edebiyat ve sanat basını büyük ölçüde dijital ortama kaymıştır ve teknoloji geliştikçe sanatın anlamı da, aktarılma biçimi de değişmiştir. 


\section{Giriş}

İlk çağlardan itibaren, estetik bir eser ortaya koymak amaciyla olmasa da sanat mevcut olmuştur. Resimde; Roman sanatı, Gotik dönem sanat1, Rönesans sanatı ve Barok dönemin ardından modern dönem sanatı hâkim hale gelmiştir. Ancak, modernlik öncesi dönemde özgürlük ve özgünlük mevcut olmadığ 1 için, sanatın aslında modernlik ile doğduğu söylenebilir. Bu dönem ile birlikte de empresyonizm (izlenimci), fovizm, ekspresyonizm, kübizm, sürrealizm ve pop sanat gibi farklı sanat anlayışları ortaya çıkmıştır. Sadece resimde değil, tüm sanat dallarında tarih boyunca dönüşümler yaşanmıştır. Toplumsal dönüşümler hem resmi, hem edebiyatı hem de diğer sanat dallarını dönüştürmüştür. Sanat dallarının hepsi, mevcut düzenin anlayışlarını aktarmanın estetik birer yolu, politik görüşleri aktarmak için birer araç, mevcut düzene yönelik birer eleştiri aracı (ki bu da toplumdaki değişime yönelik isteği yansıtmaktadır) olmuştur. Başka bir deyişle denilebilir ki tarih, sanatın anlamsal inşanın en temel araçlarından olmasına sahne olmuştur. Rubens ile Brueghel savaşı ve mücadeleyi, Caravaggio acıyı ve kederi, Munch korkuyu renklerle ve fırça darbeleri ile anlatmıştır. Marini ise heykelleri ile hava saldırılarından kaçan korku dolu insanları betimlemiştir. Nâzım mahpustan şiirle seslenirken, Necip Fazıl ülküsünü dizelere sermiştir; çünkü çaresizliğin, dayanamamanın ve acının olduğu kadar mücadelenin, fikirlerin ve anlamın da hayat bulduğu alanlar olmuştur edebiyat ve sanat. Öte yandan, "Bir anlam aramamalı. Anlam kadar insanın hayatını zehir eden bir kavram yoktur" demiştir Tutunamayanlar'da Oğuz Atay (2019: 403). O nedenle denilebilir ki; anlam kadar anlamsızlığın da aktarımı olmuştur edebiyat ve sanat. Ayrıca belki de, Walter Benjamin'in Mekanik yeniden üretim çağında sanat (1935/1993) adlı eserinde belirttiği gibi sanat yapıtının mekanik olarak çoğaltılır hale gelmesi ile birlikte anlam, hatta anlamsızlık ve sanatın kendisi de tamamen yok olmuştur.

Bu çalışmada, sanat ve edebiyatın, "üretim tarzı ve ilişkilerince belirlenen bir üstyapı ürünü” olduğu ve "alt-yapının sanat/edebiyatın içeriğini ve biçimini, yazınsal türlerin ortaya çıkması ve kalıcılaşmasını veya yok olup gitmesini belirlediği” (Kula, 2013: 9) görüşünden yola çıkılmıştır. Sanatın var oluşundan yok oluşuna kadar geçen süreçte sanat basını, gazete ve dergilerin yayımlanmaya başladığg 17 . yüzyıldan itibaren anlamsal inşanın mekânı, aracı ve temel öznesi olmuştur. Bu nedenle bu çalışmada, 17. Yüzyıldan günümüze kadar hem dünyadaki, hem Osmanlı'daki hem de sonrasında Türkiye'deki sanat ve edebiyat basınının toplumsal dönüşümler açısından nasıl bir rol oynadığı ve nasıl bir dönüşüm geçirdiği incelenmiştir. Çalışma kapsamında ilk gazetelerin ortaya çıktığ 1 yı1lardan itibaren günümüze kadar uzunca bir dönem ele alınmıştır.

Farklı dönemlerin ve farklı ülkelerin yayınlarından yola çıkarak ve tarihsel olgular dikkate alınarak bu dönüşüm incelenmiştir; çünkü günlük yaşantımızdaki herhangi bir şeyi anlamak, bu şeyin nasıl ortaya çıktığını, geliştiğini ve parçası olduğu sistem veya bağlam içerisinde nerede konumlandığı hakkında bir şeyler bilmeyi gerektirir (Ollman, 2011: 31). Bu nedenle basının herhangi bir dönemdeki tarihini, dönemin gelişmelerini değerlendirmeksizin ele almak, dönemin gelişmelerini ise belli bir toplum ile sınırlı olarak ele almak yetersiz kalacaktır. Bu nedenle bu çalışmada, basının edebiyat ve sanat ile olan ilişsisi tarihsel bir seyir ile birlikte ele alınmıştır. Bu tarihsel incelemede ise, tarihsel süreçleri ekonomi-politik gelişimler ile değerlendirmeye dayanan tarihsel materyalizm 
yöntem olarak benimsenmiştir. Bu doğrultuda, basının rolü ve hem sanatın hem edebiyatın hem de toplumun dönüşümüne etkisi, ekonomik ve politik dönüşümler dikkate alınarak çeşitli örnekler üzerinde tartışılmıştır.

\section{Yüzyıldan 21. Yüzyıla Dünyada Sanat ve Edebiyat Basınının Gelişimi ve Misyonu}

Haber mektupları ve yıllıkların ardından 17. Yüzyılda Almanya, Hollanda, Avusturya, İngiltere ve İtalya'da yayın hayatına başlayan gazetelerde edebiyat ve sanat içeriklerini görmek mümkündür. Döneminde Avrupa'nın en tanınan sanatçılarından olan Flaman ressam Pieter Paul Rubens'in varlığıyla Avrupa'nın sanat merkezi haline gelen Hollanda'nın Antwerp kentinde, 1600'lü yılların başında yayımlanmaya başlayan Nieuwe Tijdinghen gazetesinde şiirlere yer verildiği görülmektedir (der Weduwen, 2017: 48-50). Bu yıllardan itibaren, yalnızca gazetelerde değil dergilerde de edebiyat ve sanat konuları kendilerine yer bulmuştur. Örneğin, 1700'lü yıllarda İngiltere'deki The Tatler, The Female Tatler, Swift, The Intelligencer, The Spectator gibi dergiler edebi içerikler ile doludur (Raymond, 2005: 15). Sadece İngiltere'de değil, dünyanın geri kalanında da eş zamanlı olarak edebiyat ve sanat içerikli dergi ve gazetelere rastlamak mümkündür. $\mathrm{Bu}$ dönemde, edebiyatın basın ile buluşmasının merkezinde, edebiyatın politik ya da değil; ama her durumda söylenmek isteneni estetize ederek bir fikri kitlelere aktarma amacının olduğundan söz edilebilir.

\section{Aydınlanma, Fransız, Devrimi ve Özgürlük Arayışı Ekseninde Bir Mücadele Aract Haline Gelen Sanat ve Edebiyat Basını}

Jürgen Habermas (1962/1997: 140-144), İngiltere'de 1727 yılından 1735 y1lına kadar muhalefetin dergisi olan Craftsman'den örnek vererek, eskiden muhalefetin isyan ve şiddet yoluyla mücadele ettiğini, 1700'lü y1llarda ise bu tür bir mücadelenin yerini edebiyat ve basın yoluyla kurulan bir akıl yürütmenin aldığını söyler.

Edebiyat ve basın ile aktarılan akılcılığın, isyan ve şiddetin yerini aldığ bu dönem aydınlanma çağının en büyük göstergesidir. Aydınlanma ile birlikte, toplumlarda dogmatikliğe başkaldıran bir özgürlük fikri güçlenmeye başlamıştır. Basın da, bu fikrin aktarıcısı olmuştur. Ayrıca Gough'a göre (2016: 18), özgürlük fikrine paralel bir şekilde basın özgürlüğü de bu yıllarda gündemde olmuştur. Bu yıllarda, Paris’te 27 dergi ve 14 yabancı gazete özgür bir şekilde dolaşıma girebilmiştir.

1789 yılında Fransa' da başlayan Fransız devrimi ile ise sosyal ve kültürel bir reform başlamıştır. Özgürlük arayışının yanı sıra, aydınlanma ile birlikte başlayan ve adına modernlik denilen dönemde gelenekten kopuş, dogmadan kopuş, ilerleme ve akılcılık gibi fikirler değer kazanmıştır. Bu durum toplumun her alanına yansıdığı gibi sanata da yansımıştır. Dini figürlerle dolu sanatsal yapıtların yerini doğayı, sıradan insanları, günlük olayları anlatan ya da mevcut düzene karşı çıkan yapıtlar almaya başlamıştır. Örneğin, 17. yüzyılda 'Haçın Yükselişi' ya da 'Çarmıhtan İndiriliş' gibi eserleri ile tanınan Peter Paul Rubens döneminin önemli ressamlarından biriyken, 18. Yüzyılda 'Köle gemisi', 'Denizdeki balıkçılar' ya da 'Kar firtınası' gibi eserleri ile bilinen ressam Joseph Mallord 
William Turner döneminin bilinen ressamlarından olmuştur. Turner'ın 'Köle gemisi' tablosu, dönemin sorunlarından biri olan köleliğe karşı bir eleştiri niteliğindedir. Ayrıca, bu dönemlerde ortaya çıkan özgürlük arzusu beraberinde fikirleri savunmayı ve fikirler etrafında toplanmayı da getirmiştir ve basın aracılığıyla da insanların bir aradalığı sağlanabilir olmuştur.

1798-1800 yıllarında Johann Wolfgang Goethe ve Johann Heinrich Meyer tarafından Almanya'da çıkarılan Propyläen adlı dergi insanların ve fikirlerin bir araya gelebildiği bir alan oluşturmuştur. Goethe'ye göre bu dergi; 'bir basamak, bir kapı, bir giriştir, içerideki ve dişarıdaki arasında bir alandır ve hem kutsal hem de dünyevi olandır' (Allen, 2011: 3). Hem bir edebiyatçı hem de bir ressam olan Goethe'nin, Propyläen'e yüklediği anlam, basının gücünü gözler önüne sermektedir. Basının gücü ise, yalnızca sanatçıların ona yüklediği anlamdan ileri gelmemektedir. Özgünlük ve özgürlük bu dönemde dünyayı kasıp kavursa da, insanları özgürleştirmenin araçlarından biri olarak görülen sanat sanayileşme ile birlikte, kapitalist yapıyı güçlendiren bir araç olarak da rol oynamıştır ve sanat ürünleri birer metaya dönüşmüştür.

Dogmatikliğe karşı ortaya çıkan aydınlanmanın kendisinin dogmatik hale geldiğine yönelik görüşler ile (bkz. Adorno ve Horkheimer, 1944/2010) benzer şekilde, bu dönemlerde önceki dönemlerden farklı olarak ilk defa özgünlükleri ile ortaya çıkan sanat eserleri de insanları özgürleştirmek yerine köleleştirmeye başlamıştır. Başka bir ifade ile bu dönemden itibaren sanat en büyük yanılsamalardan olmuştur; çünkü çizdikçe, dinledikçe ya da okudukça dünyanın yaşanılası bir yer olduğu fikrine kapılırız.

\section{Yüzylda 1848 Devrimleri ve Feminist Hareketler ile Dönüşen Sanat ve Edebiyat Basinı}

19. yüzyılda sanat basını, sanatın gelişmesinde merkezi bir rol oynamıştır. Basın, çok çeşitli bir kitle için sanatı ulaştıran ve biçimlendiren bir araç haline gelmiştir. Bu dönemde Londra'dan Paris'e, Lahey'den Roma'ya ve Münih'e seyahat eden sanat yazarları yeni eleştirel yörüngeler oluşturmuşlardır (Clarke, 2010: 2269). Misır'da 1827 'de yayımlanmaya başlayan Jurnal al Khadyu ve 1828'de yayımlanmaya başlayan Waga'a al Masriya gazetelerinde kısa hikâyeler ve şiirler gibi edebi içeriklere yer verilmiştir (Rugh, 2003: 16). 1839 y1lında İngiltere'de yayımlanmaya başlayan Art Union dergisinde sanat ile ilgili makaleler, sanatçıların biyografileri yer almıştır (bkz. Cardiff). ABD'nin Philadelphia eyaletinde 1840'lı yıllarda çıkarılmaya başlanan beş dergi ise; Godey's, Graham's, Peterson's, Miss Leslie's ve Union, sanat galerilerine, basımevlerine ve sergilere gidemeyen insanlara ulaşarak, Amerikan sanatının dolaşımı ve demokratikleşmesi açısından önemli bir rol oynamıştır (Patterson, 2011: 11-13). Edebiyata ve özellikle de şiire gazete ve dergilerde daha çok yer ayrılmaya başlanmıştır ve ilk defa romanlar da basın aracılığıyla okuyucuya aktarılır olmuştur.

1840’l1 yıllarda Avustralya'daki gazetelerde bir ya da iki şiir yer almaktayken, 1850'lerden itibaren gazetelerde roman tefrikaları görülmeye başlanmıştır. Bulwer Lytton'un, Mary Elizabeth Braddon'un ve Charles Dickens'ın romanlarına gazetelerde yer verilmiştir (Kirkpatric, 2003: 74-75). ${ }^{1}$ Sadece batıda değil, örneğin 1847'de

1 Alan J. Lee'ye göre, İngiltere'de roman tefrikaları Avustralya'dan daha sonra 1871'den itibaren yayımlanmıştır.

Aynı dönemde ABD'de gazetelerinde de romanlar kendilerine yer bulmuştur (Kirkpatric, 2003: 74-75). 
Cezayir'de yayımlanmaya başlayan Al Mubashir dergisinin sayfalarında da şiirler yer almıştır (Kirkpatric, 2003: 75). Sanayi devriminden ikinci sanayi devrimine doğru giden ve gittikçe daha fazla küresel bir nitelik kazanan dünyanın pek çok farklı yerindeki gazete ve dergilerde şiirlere ve diğer sanatsal içeriklere yer verilmesi şaşırtıcı değildir; çünkü dünyanın pek çok yerinde benzer dönüşüm süreçleri yaşanmıştır.

Sanayi devrimi sonrası 1848 yılında Avrupa'da uzun saatler çalışma mecburiyeti, işsizlik, yoksulluk ve Avrupa'ya yayılmaya başlayan salgın hastalık insanları harekete geçirmeye başlamıştır. 1848 Devrimleri olarak da bilinen bu hareketler ile değişim fikri gündeme gelmeye başlamıştır. 1848 yılında Karl Marx ve Friedrich Engels tarafindan yazılan Komünist Manifesto da (1848/1967) dönemin şartlarının bir sonucu olarak ortaya çıkmıştır. Bu yılların devrimci ruhu, hem sanata yansımıştır, hem de sanatla dile gelmiştir. Peckham'a göre (2010: 155), 1848-1849 y1llarında oluşan devrimci ruh, kültürü kökten değiştirmeden toplumun değişemeyeceğine inanan İngiltere'de bir araya gelen ÖnRafaellocu kardeşliği de etkilemiştir.

Dante Gabriel Rossetti, Mathew Arnold, Thomas Carlyle, John Ruskin ve William Morris gibi İngiltere'de dönemin sanatçı ve entelektüellerden oluşan Ön-Rafaellocu kardeşlik, 1850 yılında oluşturdukları The Germ dergisinde resim, edebiyat ve şiire ilişkin görüşlerini yazmışlardır. Derginin hem ismi hem de içeriği, ekibin mevcut kültüre karş1 tutumunu yansıtmaktadır. Sanatın seri üretimine, dar kalıplarla belirlenmesine, kraliyet akademisi tarafindan kurallarının oluşturulmasına ve tüketime karşı çıkan bu akımın öncüleri, aşk ve sanatla biçimlenen alternatif bir dünya hayal etmişlerdir (Kayıhan, 2010: $\mathrm{v}$-11). Rosetti, en bilinen resimlerinden biriyle ilgili olan, yine en bilinen şiirlerinden biri olan 'Kutsal Genç Kız'a (The Blessed Damozel) The Germ dergisinin ilk dört sayısında yer vermiştir. Şiirinde genç kızın elindeki zambaklardan ve saçındaki yıldızlardan bahsederek, şehvetin cennetteki tezahürünü resmetmiştir (Peckham, 2010: 155). Cennette şehvetin resmedilebilir hale gelmesi, aydınlanmanın ve aydınlanma ile birlikte ortaya çıkan dogmatikliğe karşı gelişen anlayışın bir yansıması olmuştur.

Dergilerde yalnızca hâkim görüşe karşıt görüşler değil, hâkim görüşler de temsil edilmiştir. Örneğin, 1849 yılında yayımlanmaya başlayan The Art Journal'da önceleri The Clique sanatçılarına yönelik bir destek, 1850 sonrası sayılarında ise Ön-Raffaeloculuk akımına karşıt bir tutum benimsenmiştir (bkz. Cardiff). Yalnızca İngiltere'de değil, dünyanın pek çok diğer ülkesinde yayımlanmakta olan gazete ve dergilerde hem mevcut anlayışlar hem de karşıtları kendilerine yer bulabilmiştir.

1860’l1 yıllardan itibaren hikâye, şiir ve resim içerikli dergi ve gazeteler yayın hayatlarına devam etmiştir. O dönem Osmanlı İmparatorluğu topraklarına bağlı eyaletlerde de çeşitli gazete ve dergiler yayımlanmıştır. Örneğin, Tunus'ta 1861'de yayımlanmaya başlayan Al Ra'id al Tunisi, Suriye'de 1865'de yayımlanmaya başlayan Suriya in Damascus, Libya'da 1866 yılında yayımlanmaya başlayan Trablus al Maghrib, kısa hikâyeler ve şiirler gibi edebi içeriklere yer vermiştir (Rugh, 2003: 16). Amerika'da 1868 yılında yayımlanmaya başlayan ve kendisini sanat dergisi olarak tanımlayan Aldine dergisinde, Don Kişot'tan ve İncil'den çeşitli kesitler çizen Gustav Dore'nin çeşitli illüstrasyonları yer almıştır (Mott, 2002: 139). Bu örneklerden de anlaşıldığı gibi, Tunus, 
Suriye, Libya ve Amerika gibi dünyanın pek çok farklı ülkesinde, benzer dönemde sanat ve edebiyat içerikli dergiler okuyucu ile buluşur olmuştur.

$\mathrm{Bu}$ dönemde dünyada pek çok alanda olduğu gibi kadın hakları konusunda da dönüşüm yaşanmıştır. Feminist hareketin ortaya çıkmasıyla birlikte, kadınlar da bu yıllarda sanat alanında daha görünür olmaya başlamıştır. 1860'lı yıllarda İngiltere'de feminist basın ortaya çıkmıştır. Bu yıllardan itibaren English Woman's Journal, Time and Tide ve The Freewoman gibi dergilerde ve Votes for Women gibi gazetelerde edebi içeriklere yer verilmiştir. Örneğin Time and Tide dergisinde, Winifred Holtbu ve Vera Brittain'ın çalışmaları yer almıştır (Green, 2009). Dönemin kadın hakları hareketinin Amerika'daki öncülerinden biri olan Susan B. Anthony tarafından 1868 yılında çıkarılmaya başlanan Revolution gazetesinde (Keser ve Keser, 2015: 137-143), kadın hakları ile ilgili edebi içeriklere de yer verilmiştir. Sonraki yıllarda Mary Cassatt, Georgia O'Keeffe ve Frida Kahlo gibi ressamlar kadınları sanat alanında temsil etmişlerdir ve çalışmaları çeşitli dergilerde yer almıştır.

İngiltere'de 1878 yılında yayımlanmaya başlayan Magazine of Art Illustrated görsel sanatları konu edinmiştir (bkz. Cardiff). 1879'da Osmanlı eyaletlerinden olan Yemen'de yayımlanan Sanaa ve Sudan'da yayımlanan Sudania gazetelerinde yine kısa hikâyeler ve şiirler gibi edebi içeriklere yer verilmiştir (Rugh, 2003: 16). Ayrıca, 1880 yılında yayımlanmaya başlayan The Year's Art, 1893 yılında yayımlanmaya başlayan The Sketch, 1894 yılında yayımlanmaya başlayan The Yellow Book görsel sanatları konu edinmiştir (bkz. Cardiff). Bu dönemde taşımacılık ve iletişim teknolojisinde sağlanan ilerlemeler, Art Nouveau'nun uluslararası bir nitelik kazanmasına yol açmıştır. Öncelikle baskı medyasının yaygınlık kazanması, farkı ülkelerin sanatçıları arasında ilişkilerin doğmasına yol açmış ve karşılıklı olarak birbirlerinden esinlenmelerine neden olmuştur. 1890'larda çıkan birçok sanat dergisi de, bu sanatı ve tasarımı geniş halk kitlelerine tanıtma konusunda yardımcı olmuştur (Bektaş, 1992: 18). Ayrıca, farklı ülkelerdeki farklı sanat anlayışları, kimi zaman ise bir ülkede gelişen sanat anlayışına karşı ilgi basına yansımıştır. Örneğin, 1890'ların başında St. Petersburg'da başlayan Sanat Dünyas1 hareketi, Rusya'da bu dönemde kabul gören teorilerin karşıtı, ama Batı Avrupa sanatının aşina olduğu bir sanat teorisi geliştirmenin peşinde olmuştur. Hareket, dönemin popüler hareketi Peredvijniki’ye bir tepki niteliğindedir. Peredvijniki, sanat için sanatı reddederek, bunu ahlaksızlığın kaynağı olarak görmüştür (Grover, 1973: 28). 1900'lerde Rusya'da Mir iskusstva/Sanat Dünyası dergisi ise, alanında ilk örneklerden biri olarak sanat ve edebiyat içerikli dergiler için bir model teşkil etmiştir (Özakın, 2018: 242). Aynı yıl 1903 yılında yayın hayatına başlayan Camera Work dergisinde fotoğraflara, eleştirilere ve avangart sanatçıların eserlerine yer verilmiştir (Özalp, 2011: 24).

\section{Yüzyılın Savaşları ile Propaganda Aracı Olan Sanat ve Edebiyat Basını}

1914-1918 yılları arasında süren I. Dünya Savaşına tanık olan ressamlar, savaşın ardından bulundukları cepheleri tuvallerine, edebiyatçılar ise şiirlerine, hikâyelerine ve romanlarına taşımışlardır. Örneğin, İngiliz şair Rudyard Kipling'in şavaş ile ilgili bir şiiri The Times gazetesinde yayımlanmıştır (Baldick, 2015). Edebiyatta bu dönemde hiciv ve askerlerin bakış açılarını yansıtan eserler görülürken, resim alanında savaşın kendilerine 
hissettirdiklerini eserlerine yansıtan sanatçılar ile var olan sanatsal anlayışları reddeden dadaizm ve sürrealizm gibi sanat akımları ortaya çıkmıştır. Kübizm, fütürizm akımları ise, savaş sonrası dönüşüme uğramıştır. Kübist akımın öncülerinden olan Pablo Picasso, bir resminde savaşa gitmek üzere olan bir askeri resmederken, hız ve makineleşmeden etkilenen fütürizm akımı ise savaş sonrasında makineleşmenin yıkıcılığını görmüştür. Ayrıca, savaş sonrası dönemde, sanatçılar basının ve propagandanın değerinin farkında olmuşlardır.

Basının gücünün farkında olan sanatçılara verilebilecek iyi örneklerden biri, Fransa'da yaşamış İspanyol ressam Picasso'dur. 'Gitar, müzik notaları ve bardak' (Guitare, partition, verre) adlı eserinde Picasso, ikiye bölünmüş bir gazete başlığının sol alt köşesinde dış dünyadan gelen haber parçacıklarını dikkatle düzenlenmiş kompozisyonla temasa geçirerek, sanatçının anlam inşası ve kitlesel üretilen iletişim yöntemleri arasında bir karşılaştırmayı hedeflemiştir. Picasso'nun gazeteyi kendini bilen, sembolist değerlerin ironik bir olumsuzlaması olarak sınıflandırdığını düşünen eleştirmenlerin aksine, Picasso'nun resminin modern sanayinin bir aracı olan gazetelerin bile araçsallıktan sıyrılarak şiirselleştirilebileceğini yansıttığını savunan eleştirmenler de mevcuttur (Goddard, 2006: 293). Nitekim, Picasso 1901 yılında Vollard Galerisi'ndeki ilk Paris sergisinde resimlerinin bazılarını övücü değerlendirmeler yazan eleştirmenlere hediye etmiştir. 1920'li yılların başlarında eleştirmen Pierre Reverdy ile yakınlaşan Picasso, Reverdy'nin iki portresini çizmiştir. Reverdy ise Picasso'nun yeteneğini öven ve onun kübizm akımı ile sınırlı olmadığını belirten bir yazı kaleme almıştır (Fitzgerald, 1996: 117-118). Picasso gibi diğer sanatçılar da, basın ile iyi ilişkiler kurmayı önemsemişlerdir. Bundandır ki, aynı akımı benimseyen sanatçılar bir araya gelerek kendi dergilerini çıkarmışlardır.

Toplumda yerleşmiş olan anlamlara karşı çıkan bir dil ve biçim anlayışını benimseyen dada akımı 1919-1924 yılları arasında kendisine dergilerde yer bulmuştur. Bu dergilerin en önemlisi ise Fransa'da yayımlanan Littérature olmuştur (Çeken vd., 2017: 47). Bu dergi, dada akımı sanatçıları tarafından yayına hazırlanmıştır. 1930'lu yıllarda Paris'te yayımlanan üç sanat dergisi ise; Cahiers d'art, Minotaure ve Verve çeşitli sanat ekollerini temsil etmişlerdir. Henri Matisse'in çizimlerine özel bir sayı ayıran Cahiers d'art dergisi ile ilk sayılarında Salvador Dali, Jacques Lacan ve Andre Breton'a yer veren Minotaure dergisi kübizm ve sürrealizmden ilham alırken, Verve ise "sanatın demokratikleşmesi" kavramını desteklemiştir ve gelenek, gelişim ve sanatsal eğitim gibi alanları konu edinmiştir (Kolokytha, 2013: 187 -204). Verve' de yayımlanan bir yazıda Malraux'un 'kitlenin sanatı her zaman doğrunun sanatıdır. Zamanla kitleler sanata gitmeyi bırakmıştır; ama bugün kitleler sanata gitmezse, teknoloji sanatın kitlelere gitmesini sağlar' değerlendirmelerine yer verildiği görülmektedir (Kolokytha, 2013: 193). Teknoloji ve böylece ortaya çıkan yeni iletişim olanakları yalnızca sanatı kitlelere ulaştırmamıştır, sanatçıları da bir araya getirmiştir.

Yirminci yüzyılda yeni iletişim olanakları ile Nâzım'a, Brecht'e, Vallejo'ya ve daha nicelerine ait pek çok şiir dizesi farklı kıtalar ile bağ kurabilir hale gelmiştir (Berger, 2015/2018: 451). Yunan şair Yannis Ritsos'un (2002: 127) “Fransa da Rusya da Yunanistan da, Aragon da Nâzım, Neruda da Nâzım, ben de Nâzım, özgürlük ki adlarından biridir senin, o senin en güzel adın..." dizeleri de bu bağı yansıtmaktadır. 
$\mathrm{Bu}$ yıllar, sanatın teknoloji ile buluşmasına yoğun bir biçimde sahne olurken, dergilerin kimi zaman yayın hayatlarını sürdürebilmek için desteğe ihtiyaç duyması durumunu da değiştirememiştir. 1926 yılından beri Fransa'da yayımlanmakta olan Cahiers d'art dergisinin editörü Christian Zervos'un, dönemin ünlü ressamlarından Wassily Kandinsky’e yazdığı mektubunda görülebileceği gibi, 1929 yılındaki Büyük Buhran sanat basınını olumsuz yönde etkilemiştir. Kandinsky, Picasso ve Max Ernst gibi sanatçıların eserlerinin satılması ile dergi ayakta kalabilmiştir (Kolokytha, 2013: 185186). Sanat ve sanatçı, var olabilmek için basına, sanat basını ise varlığını sürdürebilmek için sanatçıların desteğine ihtiyaç duymuştur. Yine de yirminci yüzyılda, çok sayıda avangart ve soyut ekspresyonist dergi yayımlanmıştır. ${ }^{2}$

Ayrıca bu yıllar, bundan önceki ve sonraki yıllarda olduğu gibi sanatın politik yönünü yansıtmıştır. Picasso'nun "Manevi değerlerle uyum içinde yaşayan ve çalışan sanatçıların, insanlığın en yüksek değerlerini ve medeniyeti tehlikeye atan bir çatışmaya karşı kayıtsız kalmaması gerektiğini ve kalamayacağını düşündüm her zaman ve hala böyle düşünüyorum" şeklindeki ifadeleri de, politik tavrını yansıtmaktadır (Dorleac vd., 2008: 312). 1937 yılında, Joan Miro'nun İspanya iç savaşı sırasında isyan eden Katalan köylüleri resmettiği 'Orakçı' (El Segador) adlı çalışması ve Pablo Picasso'nun yine iç savaş döneminde İspanya'daki Guernica şehrininin bombalanmasını anlatan 'Guernica' adlı eseri politik tavırlarını göstermektedir. Bu duruma, Cahiers d'art ve Minotaure gibi sürrealist dergilerin sayfalarında yer verdiği diğer sanatçıların eserlerinde de rastlanabilir. Buradan yola çıkarak da, sanat basınının politik görüşlerin bir aktarıcısı olduğunu söylemek mümkündür.

II. Dünya Savaşı'nın başlamasından önce 1933'lerden itibaren Nazi sanatı, politik görüşlerin aktarıcısı olarak sanatın kullanılmasının örneklerindendir. Nazi sanat anlayışında klasik orana sahip, soluk benizli bedenler betimlenmiştir Ayrıca, Hitler Almanyası'nda propaganda bakanı Goebbel's kontrolünde sinema önemli bir sanatsal araç konumuna sahip olmuştur. SSCB gibi komünist devletlerde ise; eserlerde işçi ve köylülerin idealize edilmesi, liderlerin kült kişilikler olarak betimlenmesi ve kolay anlaşılan popülist biçimler kullanılmıştır (Gezer, 2017: 3097). 1939-1945 yılları boyunca süren II. Dünya savaş1 sırasında hem Nazi sanatı gibi savaşı destekleyen ve propaganda rolünü üstlenen hem de savaşı eleştiren eserler üretilmiştir. Rus edebiyatçı Vasili Grossman 'Yaşam ve Yazgı' adlı eserinde, savaşın yıkıcılığını anlatmıştır. Fransız yazar Patrick Modiano da, eserlerinde Nazi dönemine değinmiştir. Bu dönemde, sanatsal içeriklere de yer veren hem radyo, hem de yazılı basın yoğun bir biçimde propaganda görevini üstlenmiştir.

Elbette, gazete ve dergiler yalnızca politik görüşlerin aktarıcısı değil, estetik değerlerin de aktarıcısı olmuştur. Sert bir şekilde gazetelere karşı eleştirel bir tutum takınan sembolizm akımının öncüsü Stéphane Mallarmé bile (Drucker, 1994: 56),

2 Avangart dergilerden bazıları şöyledir: Lacerba (1913-1915), Blast (1914- 1915), Cabaret Voltaire (1916), The Blind Man (1917), Dada (1917- 1921), De Stijl (1917-1932), L'esprit Nouveau (1920-1925), Zenit (1921-1926), Mecano (1922- 1923), Merz (1923-1932), Lef (1923-1925), La Revolution Surrealiste (1924-1929), Tank (1925), Novyi Lef (1927-1929), International Revue ilo (1927-1929), Minotaure (1933- 1939), View (1940-1947), VVV (1942-1944), Avrupa ve Amerika dışında ise Japonya'da Gutai (1955-1965), Arjantin'de Boa (1958-1960) gibi dergiler yayımlanmıştır. Iconograph (1946), The Tiger's Eye (1947- 1949), Possibilities (1947-1948), Instead (1948), It Is (1960-1965) savaş sonras1 soyut ekspresyonizm dergileridir (Allen, 2011: 3). 
çeşitli vesilelerle, gazeteyi şiirsel fikirlerin ifadesi için ideal bir araç olarak aktif olarak tanıtmıştır (Goddard, 2006: 298). Basın, fikirlerin aktarıcısı olduğu kadar yeni fikirlerin yaratıcısı da olmuştur. 1950'lerde Almanya'da yayımlanan ZERO dergisi, taşizm gibi öznel savaş sonrası akımlara karşıt yeni estetik kriterleri savunan bir sanat akımını meydana getirmiştir (Ketner II, 2017: 71). Medya ve tekniğin yeni yönlerini kullanan akım, imgeleri meydana getirmek için tek renklilikten, 1ş1ktan, ateşten ve medyadan faydalanmıştır (Pörschmann, 177). 1960 yılında Fransa'da o dönemde tanınmayan bir grup tarafından yayımlanmaya başlayan Tel Quel dergisi ise, Nietzsche'nin “Dünyay1 istiyorum ve onu olduğu gibi istiyorum, hala ve sonsuza dek istiyorum ve haykırmak için bağırıyorum: isteriz! Ve sadece kendim için değil, tüm oyun için ve tüm gösteri için; ve sadece tüm şov için değil, gerçekten benim için istiyorum, çünkü şova ihtiyacım var - çünkü şov beni vazgeçilmez k1lıyor - çünkü bana ihtiyacı var ve ben onu vazgeçilmez k1lıyorum" sözünden alıntıyla başlayarak, Varoluşçu yazarlar Jean-Paul Sartre ve Albert Camus'nun edebiyat anlayışından uzak, dünyayı bir bütün olarak benimseyen önyargısız bir tutum benimsemiştir. 'Olduğu gibi' anlamına gelen ismi ile hem düşünür Friedrich Nietzsche'ye hem de şair ve yazar Paul Valéry'e göndermede bulunan dergi (Kauppi, 2013: 25-27), Fransa' da yeni bir anlayışa öncülük ederek bir dönüşüm yaratmıştır. Ayrıca, Tel Quel yazarları Çin şiirleri ve Maoizm ile de ilgilenerek, Batı'nın bastırılmış ideolojilerini ve öznelliklerini aşan küresel bir bakış benimsemişlerdir (Hayot, 2009: 128). Mevcut düzene yönelik isyan, hem resim, hem edebiyat hem de diğer sanat dallarının hem öznesi hem de nesnesi olmuştur.

\section{Yeni Teknolojiler ile Geleneksel Sınırlarını Aşmaya Başlayan Sanat ve Edebiyat} Basinı

1960’larda da dergiler sanatsal yeniliklere sahne olmuştur. Tek renkli (monokrom) resimleriyle tanınan sanatçı Bernard Aubertin, Revue Integration dergisinin bir sayfasına üç kibrit yapıştırıp yakarak sayfada yanık izi bırakmıştır. Basılı bir sayfanın maddeselliğini ve geçiciliğini yansıtan bu gibi denemeler (şiirde de benzeri denemeler mevcuttur), katı bir biçimde olmak yerine eylemsel, geçici ve kavramsal olan yeni sanat aracı anlayışı ile örtüşmektedir. Aubertin ve benzeri sanatçılar, bu gibi denemeler ile hareketsiz ve iki boyutlu sayfanın geleneksel sınırlarını aşan uygulamalar geliştirmişlerdir (Allen, 2011: 6). Ayrıca bu yıllarda dergiler, sanat akımlarını galerilerden bile daha çok görünür kılmıştır. Sanat eleştirmeni Arthur C. Danto (1997/2014: 156), 1962 baharında Paris’te dönemin önemli sanat yayınlarından olan Art News'te Roy Lichtensein'ın 'Öpücük' (The Kiss) adlı eserini basılmış olarak gördüğü anı şöyle anlatır:

\footnotetext{
Pop'u, neredeyse Avrupa'daki herkes gibi, tıpkı bugünkü gibi o zaman da sanatsal etkinin başlıca taşıyıcısı olan sanat dergileri aracılığıyla keşfettim. Sersemlediğimi itiraf etmeliyim. Bunun dudak uçuklatan ve kaçınılmaz bir an olduğunu biliyordum; böyle bir resim üretmek ve önde gelen bir sanat yayınının da bunu üzerine yazacak kadar ciddiye alması mümkünse her şeyin mümkün olduğunu o an kavradım. Tam o anda aklıma gelmedi ama şayet her şey mümkünse, muayyen hiçbir gelecek yoktu gerçekten; şayet her şey mümkünse, benim sanatsal gelecek vizyonum da dahil hiçbir şey gerekli ya da kaçınılmaz değildi. Bu benim için şu anlama geliyordu: İnsanın, sanatçı olarak canı ne isterse onu yapmasinda bir sorun yoktu.
}

Pop sanat, yalnızca sanatın ne olduğuna yönelik görüşümüzü değiştirmemiş, aynı zamanda sanat eserini de hiç olmadığı kadar kapitalist piyasanın bir aracı haline 
dönüştürmüştür. Pop sanat ve benzeri akımların ortaya çıtığ 1 1960'lar, kimi düşünürler tarafından post-modern dönem olarak tanımlanırken, kimi düşünürler tarafından ise kapitalizmin bir devamı olarak tanımlanmıştır. Resimlerde artık fakirliği, yoksulluğu anlatan ya da bize ne düşünmemiz gerektiğini sunan eserler yerine, gerçekliği sorgulayan, bambaşka gerçeklikleri düşündüren eserler ortaya çıkmıştır. Buna karşın yeni teknolojilerle birlikte tüketim hiç bir zaman olmadığı kadar önemli hale gelmiştir. Böylece, gittikçe artan bir biçimde sanat ve edebiyat; sınıf tahakkümünü daha meşru kılmıştır (Ayaz, 2016: 121-124). Anlamın ve sabit anlatıların ortadan kalktı̆̆1 1960'lar ve 1970'ler boyunca dergiler, ABD'de sanatçıların eserlerini sergilemeleri için alternatif bir alan oluşturmuştur. Yeni sanat anlayışı, kaideleri ve tuvalleri terk ederek metinlere ve fotoğraflara dayanan bir anlayış benimsemiştir. Sanat tarihçi David Rosand, sanat dergilerinin yeni rolünün gelişmeleri takip etmek olduğunu aktarmıştır. İnsanlar olup biteni sanat galerilerinde görememektedir; çünkü artık sanat olarak kabul edilenler galerilerde mevcut değildir. $\mathrm{Bu}$ dönem yeni iletişim teknolojilerine bağlı sanatı çoğaltma anlayışını da yaygınlaştırmıştır. Sanatın kitle iletişim araçları ile dağıtıldığını ve yeniden üretildiğini belirten Walter Benjamin, 'Mekanik yeniden üretim çağında sanat' (1935/1993) adlı eserinde bir sanat yapıtının mekanik olarak çoğaltılmasının eserin ruhunu yok ettiğini, zaman ve mekândaki biricikliğini yitirdiğini savunmuştur. Ancak, Benjamin ayrıca yeni teknolojiler ile üretilen sanatın aynı zamanda yeniden üretilebilir nitelikte tasarlanan sanat olduğunu belirtmiştir. Ayrıca, Benjamin, Bertolt Brecht ile birlikte, Krise und Kritik (Kriz ve Eleştiri) adlı bir dergi çıkarmayı planlamıştır; ancak bu proje hayata geçememiştir (Allen, 2011: 1-2). 1962 yılında gerçekleştirilen bir araştırmada ise, sanat dergilerinin okunmak için değil bakılmak için tasarlandığı sonucuna ulaşılmıştır. Bu yıllarda Jasper Johns'un bir resminin Art News dergisinin kapağında yer almasının ardından New York’taki Modern Sanat Müzesi'nin (MoMA) ilk direktörü Alfred H. Barr'ın, dergide resimlerle ilgili kayda değer bir yazı kaleme alınmamış olmasına rağmen Johns'un üç resmini satın alması dergilerde bir resmin reprodüksiyonun yer almasının önemini yansitmaktadır (Allen, 2011: 2324). Kısacası bu dönemde, sanat galerilerinden daha çok sanat dergileri sanat eserinin satılmasına aracı olmuştur.

Dergi ve gazetelerin iki boyutlu biçimini aşma isteği, 1965 yılında itibaren Amerika'da yayımlanan multi-media içerikli Aspen dergisi ile yeni bir boyut kazanmıştır. Dergi her sayısında resimleri, filmleri, ses kayıtlarını ve reklamları içeren bir kutu ile beraber çıkmıştır. Derginin pop sanat sayısı olarak çıkan üçüncü sayısı ise Andy Warhol ve David Dalton tarafından tasarlanmıştır ve bu sayıdan itibaren dergi ile birlikte verilen kutular 1960'ların avangart düşüncesini yansıtmıştır. McLuhan sayısı ve minimalist sayı da derginin dikkat çeken sayıları olmuştur (Hothi, 2012: 33). Cage, J. G. Ballard, John Lennon ve Susan Sontag gibi sanatçılar dergiye katkı sağlamışlardır (Gageldonk, 2010: 48). Bu yıllarda yalnızca aracın yapısı değil, anlamı da sorgulanmaya başlanmıştır. Artforum dergisinin 1966 yılındaki kapağında Frank Stella'nın bir eserine yer verilmiştir (Artforum, 2020) Amerikalı kavramsal sanatçı John Baldessari ise 1968 yılında, Artforum dergisinin 1966 yılındaki sayısının kapağına "Bu bakılmak için değildir" (This is not to be looked at) ifadesini ekleyerek bu kapağ yeniden yorumlamıştır (Allen, 2011: 23). Bu kapakla Baldesarri, Stella'nın "Gördüğünüz, gördügünüzdür" (What you see is what you see) fikrine ve bununla birlikte modern estetiğin görsellik egemenliğine karşı çıkmıştır 
(Artforum, 2020). Sanatın yapısı ve anlamı dönüşürken, sanat basınının bir fikri aktarma ya da mevcut düzeni dönüştürme misyonu değişmemiştir.

İsmini Ekim Devrimi'nden alan October dergisi 1970'lerde mevcut sanatsal söylemi dönüştürme amaciyla kurulmuştur. Hem Jacques Derrida, Michel Foucault, Julia Kristeva gibi kuramciların, hem de Daniel Buren, Tricia Brown, Laurie Anderson, Samuel Beckett gibi sanatçıların metinlerinin yayımlandığı dergi, kuram ve uygulama arasında bir kesişimi amaçlamıştır (Allen, 2011: 28). 1970-1976 yılları arasında New York'da yayımlanan Avalanche dergisi ise, kavramsal sonrası sanatı ve 1970'lerin New York'unda mevcut olan sanat manzarasını yansıtmıştır (Ballmer, 2011: 21). Eleştiri çağından röportaj çağına geçişi yansıtan dergi, Amerikan halkının ünlülerin özel yaşamlarına duyduğu ilgiye hitap eden eleştiri karşıtı bir tutum benimsemiştir. Dergide görünür olan sanatçıların satışları artıyor olsa da, derginin editörü bu pazara karşı olmamakla beraber asıl amaçlarının satmak değil, sanatçılar ile röportajlar yaparak bu sanatçılara yönelik farklı bir kamusallık oluşturmak olduğunu belirtmiştir. Derginin, pahalı olmayan ve demokratik formatı, alternatif sanata yer vermesi ve tam sayfalık savaş karşı1tı reklamları materyalist olmayan ruhunu yansitmaktadır (Allen, 2005: 51-52). 1970'lerden sonra, dijital teknolojilerin hızla gelişimi ile birlikte, edebiyat ve sanat basını büyük ölçüde dijital ortama kaymıştır. Böylece, Amerika'da Aspen dergisi ile başlayan iki boyutlu sayfa biçimini aşma isteği zirveye ulaşmıştır. Hem biçim, hem içerik, hem de anlam dönüşmüştür. Günümüzde, uzun yıllardır basılı olarak yayın hayatı devam eden dergi ve gazetelerin bir kısmı tamamen dijital yayına geçiş yaparken, bir kısmı ise hem basılı hem dijital ortamda varlıklarını sürdürmektedir.

\section{Osmanlı'dan Günümüze Türkiye'de Sanat ve Edebiyat Basını}

Osmanlı'dan günümüze kadar hem edebiyatta hem de görsel sanatlarda dönüşümler yaşanmıştır. Osmanlı' da süsleme, resim sanatı açısından önemli rol oynasa da, resimler kimi zaman gücü ve güçsüzlüğü ifade etmenin de araçları olmuştur. Örneğin, 15. Yüzyılda Fatih Sultan Mehmet'in İtalyan ressam Bellini'ye sipariş vererek yaptırdığı portresi gücünü resmederken, 17. Yüzyılda Avrupalı çeşitli ressamlarca resmedilen padişahların korkularını anlatan, garip kıyafetler içinde ve anatomik bozukluklar ile resmedilmesi, resimlerin propaganda amacına sahip bir iletişim biçimi olduğunu ortaya koymaktadır (Gülaçt1, 2017: 33- 35). Padişah portreleri ve minyatürler ile başlayan Osmanlı sanatı açısından nakkaşlar önemli rol oynamıştır. Divan edebiyatı ve halk edebiyatı ise Osmanlı döneminde varlığını sürdüren edebi akımlar olmuştur. Osmanlı'da sanat ve edebiyat sarayın içinde bile var olmuştur; öyle ki Yavuz Sultan Selim şiirle, Abdülmecid ise resim ile ilgilenmiştir. 18. Yüzyıldan itibaren başlayan batılılaşma hareketi ve sanayi devrimi ile değişen anlayışlar ve üretim tarzı, diğer her alanı olduğu gibi hem resim sanatını hem de edebiyatı etkilemiştir. Primitifler, asker ressamlar, Osman Hamdi Bey ile başlayan figüratif resim ve Sanayi-i Nefise Mekteb-i resim ve heykel sanatını zenginleştiren öğeler olmuştur. Osmanlı Ressamlar Cemiyeti'nin kurulmasının ve Avrupa'ya sanat eğitimi almaya gidenlerin geri dönmelerinin ardından görsel sanatlarda bir dönüşüm gerçekleşmiştir. Benzer bir dönüşüm edebiyat alanında da yaşanmıştır. Tanzimat 
dönemiyle birlikte, divan edebiyatı yerini dilde sadeleşmeye ve Servet-i Fünûn ile birlikte yeni anlayışlara bırakmıştır. İzlenimci ressamlar, Müstakil Ressamlar ve Heykeltıraşlar Birliği, daha çok kübizm ve soyut sanat ile ilgilenen D Grubu, Türk resim tarihi açısından önemli rol oynarken, Milli edebiyat akımı, dil devrimi, Garip akımı, Yedi Meşaleciler hareketi, İkinci Yeni ve Toplumcu gerçekçiler Türkiye'nin edebiyat tarihi açısından önemli rol oynamıştır. Basın da, edebiyat ve görsel sanatlar alanında yaşanan bu dönüşümlerin kimi zaman aktarıcısı, kimi zaman ise yaratıcısı rolünü üstlenmiştir. Gazetelerin ilk defa Türkçe olarak yayımlandığı tarihlerden başlayarak hem gazetelerde hem de dergilerde sanat ve edebiyat konularına yer verilmiştir.

\section{Ilk Gazeteler ile Birlikte Sanat ve Edebiyat, Tanzimat Döneminin Yansımaları}

1831 yılında yayımlanmaya başlayan İlk Türkçe gazete Takvim-i Vekayi'de sanata hiç yer verilmemiş olsa da, 1840'da yayın hayatına başlayan Ceride-i Havadis'de edebiyat ve tiyatro konularına, 1860 yılında yayımlanmaya başlayan Tercüman-l Ahval'de ise edebiyat içerikli konulara yer verilmiştir (Çıkla, 2009: 36). Şinasi'nin Şair Evlenmesi piyesinin tefrikası da bu gazetede yayımlanmıştır (İskit, 1937: 23). Berkes'e göre (2004: 262) dil ve edebiyat çağdaşlaşmasının öncüsü olan Şinasi, halk sözlerinin edebi değerinin önemini göstermiştir. Şinasi tarafından kurulan ve döneminde tirajı oldukça yüksek olan Tasvir-i Efkâr'da şiir ve diğer edebi içeriklerin yayımlanmasıyla, edebiyat belli bir sınıfın ilgisi olmaktan çıkarak halkın ilgisi olmaya başlamıştır (Tanpınar, 1997: 250-251). Tanpınar'a göre (1997: 5) roman, tiyatro, makale, tenkit ve deneme gibi türlerin Türk edebiyatı ile tanışması ve yaygınlaşması gazeteler ve dergiler yoluyla gerçekleşmiştir.

Ayrıca, bu dönemin gazetecilerinin çoğu aynı zamanda edebiyatçılardır ve bu durum gazetelere de yansımıştır. Ziya Paşa, Ali Suavi, Mustafa Fazıl Paşa, Namık Kemal, Reşad Bey, Mehmed Bey ve Rıfat'ın öncülüğünü yaptı̆̆ 1 Yeni Osmanlılar adı verilen grup (Mardin, 2015) yayınlarında politik konulara olduğu kadar edebi ve sanatsal konulara da yer vermiştir. Örneğin, Namık Kemal İbret gazetesinde yayımlanan "Tiyatro" adlı yazısında tiyatroya duyulan ihtiyaca değinmiştir (Ayaz, 2017: 637). Ayrıca, Tanpınar'a göre (1997: 250) dönemin önemli şairleri olan Recaizade Mahmud Ekrem ve Muallim Nâci de gazetelerde yetişmiştir. Bu dönemde edebiyatın basına etkisini yansıtan bir olay ise, 1873 'te Vatan Yahut Silistre piyesinin ardından gazetelerin yayın süreçlerinin askıya alınmasıdır (Çıkla, 2009: 44). Bu dönemde, Osmanlı' da da dünyada olduğu gibi, isyan ve şiddet yoluyla mücadelenin yerini, edebiyat ve basın yoluyla kurulan bir akıl yürütmenin aldığı görülmektedir. Ayrıca, 1840'lı yıllarda dünyanın geri kalanında başlayan değişim hareketleri, ayaklanmalar şeklinde Osmanlı' ya yansımamış olsa da, Osmanlı' da da benzer y1llarda bir değişim ve özgürlük arzusunun olduğu söylenebilir. Nitekim, Meşrutiyet'in ilanına kadar süren modernleşme ve reform dönemi olarak da bilinen Tanzimat dönemi de bu durumu doğrulamaktadır.

$\mathrm{Bu}$ dönemde hem üretim biçimleri hem de politik yapı bir değişim geçirmiştir. Sanayileşme ile birlikte fabrikalara yönelen Osmanlı'da sancaklar hükümdar adına yönetilirken, modern mahalli yönetim biçimleri Tanzimat ile birlikte biçimlenmiştir. Tanzimat Fermanı ile özel mülkiyet güvence altına alınırken, Kânûn-1 Esâsî ile birlikte insanların özgürlükleri kanunla korunur hale gelmiştir. Osmanlı'nın ekonomi-politik 
yapısının değişimi, üst yapıyı da etkilemiştir. Başka bir deyişle denilebilir ki; üretim tarzındaki değişim; yenilik, özgürlük ve değişim arzusu ile birlikte edebiyata, sanata ve basına yansımıştır.

Tanzimat'tan sonra da bazı gazeteler edebî ilaveler vermişstir. Tercümân-ı Hakîkat, Sabâh, Tarîk, İkdam, Terakkî, Peyam, Alemdar, Türk Dünyası sayfalarında edebiyata yer veren ya da edebî ilave veren gazetelerdendir (Çıkla, 2009: 42-45). Yalnızca gazeteler değil, dergiler de Tanzimat ve sonraki dönemlerde sanat içeriklerini okuyucu ile buluşturmuştur. Gazetelerin yayınlarının durdurulması da, bu yönelime neden olmuştur. 1888 yılında Mürüvvet gazetesinin eki olarak çıkan Mürüvvet dergisinde kadın yazar ve şairlerin edebiyat içerikleri yer almıştır (Kılıç, 2015: 752). Dergide, Nigâr Hanımın ilk şiirleri, Nigâr bint-i Osman, Leyla Saz ve Fitnat Hanım'ın eserleri yayımlanmıştır (Doğan, 2012: 83). Osmanlı'da, Tanzimat dönemi aynı zamanda kadınların toplumsal hayata katılmaya başladıkları bir dönem olmuştur. Mürüvvet dergisinin de, bu anlayışın bir sonucu olduğu düşünülebilir. Bu dönemde, toplumsal hayata katılımın ise belli bir zümreye ait kadınlar için daha mümkün olduğu söylenebilir. Örneğin, dergide çalışmaları yayımlanan hem Fitnat Hanım hem de Leyla Saz kültür seviyesi yüksek birer aileden gelmektedir.

1891 yılında yayın hayatına başlayan Servet-i Fünûn dergisi, 19. Yüzyılda edebî toplulukların oluşmasında ve yeni edebiyat anlayışlarının yerleşmesinde önemli bir rol oynamıştır (Dirin, 2009: 224). Hatta, Servet-i Fünûn devri (Edebiyat-1 Cedîde) de adını bu dergiden almıştır (Akdik, 2018: I-III). Servet-i Fünûn dergisi, yazı işlerine Tevfik Fikret'in getirilmesiyle edebiyat ve sanat dergisi halini almıştır. Dergiyle aynı adı taşıyan topluluk, eski edebiyatın terk edilerek Batı'dan alınan yeni biçimlerin benimsenmesi gerektiğini savunmuştur (Akyüz, 1995: 88). Servet-i Fünûn edebiyatında bireysel konulara ağırlık verilmiş, şahsi duygu ve yaşantılar karamsar bir bakışla sunulmuş, hayal-hakikat çatışması, toplumdan kaçış arzusu, tabiata sığınma, melankoli ve hastalık izlekleri işlenmiştir. Ayrıca, Servet-i Fünûn edebiyatında doğa konuları işlenmiştir. Doğa, içinde bulunulan çevre ile sınırlandırılmamış, ruhsallığın keşfedildiği derinliği olan bir olgu olarak ele alınmıştır (Akdik, 2018: I-III). Resim de derginin kapsadığı konulardan olmuştur. Örneğin, Türkiye'de konstrüktivizmin (geometrik-figüratif yapımcılık) öncülerinden olan Nurullah Berk, bu dergide çıkan bir yazısında sanat ortamını ve algısını eleştirmiştir (Özaltın, 2016: 50). Güzel Sanatlar Akademisi'nde, Hikmet Onat, İbrahim Çallı ve Léopold Lévy atölyelerinde öğrenim gören Nuri İyem'in desenleri de henüz öğrenciyken Servet-i Fünûn dergisinin çeşitli sayılarının kapaklarında basılmıştır (Günay, 2011: 19-20). Soyut-nonfigüratif sanat çalışmalar yapan İyem, bu y1llarda Yeditepe ve Dost dergileri için de sanat yazıları yazmıştır (Günay, 2011: 21).

\section{Yüzyılda Savaşların Hem Sanata, Hem de Sanat ve Edebiyat Basınına Yansımaları}

1908 yılında Sırat-ı Müstakim adıyla çıkarılmaya başlanan ve sonradan Sebîllüreşâd adını alan dergi de, edebi konulara yer vermiştir (Sadıkoğlu, 2013: 9). 19. ve 20. Yüzyılda gazete ve dergilerin ilgisi daha çok edebiyata, tiyatroya ve müziğe yönelik olsa da, görsel sanatlar da yayınlarda kendilerine yer bulabilmiştir. 19. Yüzyılda Pera merkezinde 
toplanan ressamlar, hem birbirlerini eleştirmeye, hem de tanımlanmış estetik değerler ile ilgili eleştiriler yazmaya başlamışlardır. Sanat eğitimi, hat sanatı ve batılı anlamda sanat üretimine değinen konuları içeren Osmanlı Ressamlar Cemiyeti Gazetesi bu içerikte yazılara zemin olmuştur (Özaltın, 2016: 39-47). Hikmet Onat, İbrahim Çallı ve Şevket Dağ gibi pek çok ressamı ve bu ressamların eserlerini tanıtan Osmanlı Ressamlar Cemiyeti Gazetesi sayfalarında Ressam İzzet Ziya'ya özel olarak sipariş verilen III. Selim portresine de yer vermiştir.

O y1llarda Pera'da Salon sergileri düzenlenmektedir ve Konstantinapolis'li Sanatçılar Derneği kurulmuştur. Pera'da Fransızca olarak yayımlanmakta olan Stamboul Gazetesi'nde Pera'daki sanat ortamındaki gelişmelerden bahsedilmiştir (Özaltın, 2016: 45). Ayrıca, asıl ilgisi resim olmayan dergilerde de resimlere yer verildiği görülmüştür. 1909-1910 yıllarında yayımlanan Musavver Hâle dergisinin 3.sayısında ressam Celile Hikmet imzalı bir tabloya yer verilmiştir (Polat ve Yaygın, 2019: 177). Yine de resim ve diğer görsel sanatlardan daha çok, edebiyat basına yansımıştır.

$\mathrm{Bu}$ dönemlerde basındaki edebi içerikler kimi zaman politik tavırların, çeşitli fikirlerin kendilerini gösterebilmesine olanak tanımıştır. 1911 yılında Selanik'te çıkarılan Genç Kalemler dergisi ile Türkçülük akımı edebiyata yansımıştır. Ömer Seyfettin, Âkil Koyuncu, Râsim Haşmet ve Ali Cânib tarafından çıkarılan dergi, ilk kez 'Millî Edebiyat' kavramını ortaya atmıştır (Sadıkoğlu, 2013: 3). Basın tarafından aktarılan edebi metinler yoluyla politik görüşler daha geniş kitlelere ulaşabilir olmuştur.

$\mathrm{Bu}$ yıllarda, I. Dünya Savaşı'nın sanata yansımaları olmuştur. Sanayi-i Nefise Mektebi'nin 1910 yılında açtığı sınavı kazanarak yurt dışına resim sanatı eğitimi için giden ressamlar, 1914'de savaşın başlaması üzerine ülkeye dönerler ve yurt dışında aldıkları resim eğitimi ile ülkemizde yeni bir sanat anlayışını yaratırlar. Bu nedenle de 1914 Kuşağı olarak anılmakta olan bu ressamlar grubu, izlenimciliği benimsemiştir. Ayrıca bu yıllarda, birçok sanatçı I. Dünya Savaşı ve ardından Kurtuluş Savaşına katılmıştır ve yaralanmış ya da şehit olmuştur. Asker ressamlar nedeniyle, savaş temalı konular sanat eserlerine yansımıştır (Keskin, 2014: 268-270). Hikmet Onat, 'Siperde Mektup Okuyan Askerler' tablosunu, Sami Yetik ise 'Hücuma Kalkış' adlı tablosunu bu dönemde yapmıştır. Görüldüğü gibi, I. Dünya savaşı dünyada olduğu gibi Osmanlı’da da sanata yansımıştır. Ayrıca, 1914 kuşağının resimleri sıklıkla, Osmanlı Ressamlar Cemiyeti Gazetesi'nin sayfalarında yer almıştır.

1919- 1920 yılları arasında yayımlanan Türk Dünyası gazetesinin ilavelerinde Mehmet Emin Yurdakul, Reşat Nuri Güntekin, Köprülüzâde Mehmed Fuad, Ömer Seyfeddin, Yusuf Ziya Ortaç, Orhan Seyfi Orhon, Faruk Nafiz Çamlıbel gibi dönemin ünlü şair ve yazarlarının çalışmaları yayımlanmıştır (Çıkla, 2009: 42-45). I. Dünya savaşının sonuna doğru İttihat ve terakkinin sözcüsü Ziya Gökalp'in öncülüğünde çıkan Yeni Мecтиa propagandaya değil milli kimliğe yönelmiştir (Köroğlu, 2004). Bu yıllarda başlayan milli mücadele yıllarında Mehmet Âkif Ersoy'un 'İstiklâl Marş1', Yahya Kemal'in Hâkimiyet-i Milliye gazetesindeki köşe yazıları, Halide Edip’in ‘Ateşten Gömlek’ ve Yakup Kadri’nin 'Yaban' romanları Millî Mücadele ruhunu yansıtan eserlerdendir (Tonga: 189). Ayrıca bu yıllarda, Mehmet Âkif Ersoy gibi isimlerin eserlerinin yer aldığı Sebîllüreşâd dergisinde (Sadıkoğlu, 2013: 9), İstiklal Marşı'da ilk defa yayımlanmıştır. 
1919 yılından itibaren ressam İzzet Ziya'nın resimleri, Sedat Simavi tarafından çıkarılan İnci ve Yedigün dergilerinde, Yeni Kitap dergisinde ve Resimli Gazete' de yer almıştır. Yeni Kitap ve Yedigün dergilerinde en az iki yüz on beş çalışması yer alan İzzet Ziya bu dergilerde yer alan çalışmalarında çoğunlukla insanları, çeşitli roman ve hikâyeleri resmetmiştir (Çeri ve Birinci, 2014: 12-13). Bu dergilerde, yalnızca İzzet Ziya'nın değil diğer ressamların çalışmalarına da yer verilmiştir.

Kurtuluş Savaşı döneminde yayımlanmaya başlayan Hâkimiyet-i Milliye gazetesinde ise Galatasaray resim sergileri ve Ankara resim sergileri ile ilgili yazılar yer almıştır. Örneğin, Ankara'nın başkent ilan edilmesinden bir gün sonra açılan I. Ankara Resim Sergisi ile ilgili olarak gazetede; "Türk resminin artık vücut bulduğunu ispat eder nitelikte olgun eserler vermeye başladığı, özellikle son senelerde ortaya koyduğu başarılı ve ileriye dönük adımlarla gelecek Türk resim sanatının temellendiği”" ifade edilmiştir (Özyiğit, 2017: 187-188). Resim ve diğer sanat dallarına olan ilgi Cumhuriyet döneminde de devam etmiştir.

\section{Cumhuriyet Yilları ve Sonrasında Sanat ve Edebiyat Basını}

Cumhuriyet yıllarında "İnsanlar olgunlaşmak için bazı şeylere muhtaçtır. Bir millet ki resim yapmaz, bir millet ki heykel yapmaz, bir millet ki tekniğin gerektirdiği şeyleri yapmaz; itiraf etmeli ki o milletin ilerleme yolunda yeri yoktur" ve benzeri sözleriyle Mustafa Kemal Atatürk (1997: 71), pek çok kez resme ve sanata verdiği önemi anlatmıştır. Ayrıca Cumhuriyet' in ilk yıllarında başkent Ankara' da ikinci bir resim sergisi açılması ve açılışa bakanlık seviyesinde katılımlar sanata hükümet tarafindan verilen önemi göstermektedir (Özyiğit, 2017: 189). Cumhuriyetin kurulmasından itibaren özellikle edebiyat ${ }^{3}$, tiyatro ve müzik ${ }^{4}$ konuları dergilerde tartışılmaya devam etmiştir. Bu yıllarda, Millî Mecmua (1 Kasım 1923 - Mart 1955, 162 Say1), Hayat (2 Aralık 1926 - 30 Aralık 1929, 146 Sayı), Yeni Türk Mecmuası (Ekim 1932 - 1942, 117 Sayı) gibi genellikle Ankara merkezli dergilerin idealist bir çıkışı, uzun soluklu ve kapsayıcı bir yayın hayatı olmuştur (Apaydın ve Özakman, 2019: 15). Cumhuriyet döneminde de önceki dönemlerde olduğu gibi tefrikalar gazetelerde kendilerine yer bulmuştur. Örneğin, Çalıkuşu ilk önce 1922'de Vakit gazetesinde tefrika edilerek yayımlanmıştır. Ayrıca, Refik Halit'in 1922'de çıkardığı Aydede mizah gazetesinde çok sayıda edebiyatçı yazmıştır. Bunlardan bazıları, Reşat Nuri, Yusuf Ziya, Yahya Kemal, Yakup Kadri, Rıza Tevfik, Enis Behiç ve Peyami Safa'dır (Çıkla, 2009: 48-51). 1923 yılından itibaren Hayat Mecmuası,

\footnotetext{
3 1920'li yıllardan itibaren çok sayıda edebiyat dergisi yayın hayatına başlamıştır. Bunlardan bazıları şunlardır: Amaç, Alan '67, Aramak, Arayış, Ayane, Barbaros, Beş Sanat, Bizim Yayla, Cemre, Çăgdaş Eleştiri, Çă̆ımız, Çă̆layan, Çı̆̆, Defter, Değirmen, Dergâh, Devinim, Diriliş, Doğuş, Doğuş Edebiyat, Dönem, Dönemeç, Edebiyat, Edebiyat Âlemi, Edebiyat Dostlar, Edebiyat Dünyası, Erguvan, Esi, Filiz, Fuzulî, Gelecek, Gelişme, Güldeste, Gülpınar, Hamle, Hasandağı, Hisar, Hürriyet Gösteri, Işınsu, İç Kaynak, İde, İleri Türk Özü, İlkyaz, İslâmî Edebiyat, İstanbul, İşte, Kalem, Kara İnci, Kardaş Edebiyatlar, Karşı Edebiyat, Kayıtlar, Kırkgöz, Küçük Dergi, Mavera, May, Meşale, Nilüfer, Oluş, Onüç, Resimli İstanbul Haftası, Türkiye Defteri, Türk Sanatı, Ürün, Varan, Sanat Edebiyat, Sanatlar, Sed, Sedir, Şelale, Tercüme, Toprak, Türk Dili, Türk Dili ve Edebiyatı Dergisi, Yaprak, Yarın, Yazı, Yazko Edebiyat, Yeditepe, Yedi İklim, Yelken, Yeni Edebiyat I, II, Yeniden Doğuş, Yeni İnsan, Yeşil Yurd, Yordam (Dirin, 2009: 227-264).

41931 yılından itibaren Musikî, Müzik ve Sanat Hareketleri, Musikî Mecmuası, Musikî ve Nota adlı dergilerde müzik ile ilgili konulara değinilmiştir. Küçük Sahne, Türk Tiyatrosu, Yeni Adım, Tiyatro Dergisi:, Tiyatro I, II, Sahne, Perde ve Sahne, Resimli Hayat, Ístanbul Operası dergilerinde ise tiyatro, sinema ve operayla ilgili içeriklere yer verilmiştir (Dirin, 2009: 247- 261).
} 
Fikirler, Meşale ve Resimli Ay gibi sanat içerikli dergiler yayımlanmıştır (Sülün: 2009: 93-95). 1924 yılında yayımlanmaya başlayan Resimli Ay dergisi, Nazım Hikmet'in de aralarında olduğu sanatçıların başlattığı "Putları Yıkıyoruz" kampanyasına sahne olmuştur. Aydınların politik saflarını aldığı bu dönemde, dergiler belli fikirlerin temsilcisi yazarların buluştuğu bir çatı haline gelmiştir (Maral İşaşır, 2006: 7). Aydınlık dergisinde de Nazım Hikmet' in şiirleri yer almıştır (Maral İşaşır, 2006: 10). Ayrıca, Nazım Hikmet' in şiirleri dünyanın farklı ülkelerindeki dergilerde de yayımlanmıştır. Örneğin, John Berger (2015/2018: 451), Nazım Hikmet' in bazı şiirlerini okuduğunda henüz çok genç olduğunu ve Nazım'ın şiirlerine o dönemde uluslararası bir edebiyat dergisinde rastladığını söyler. Bu yıllarda yayımlanan Kültür Haftası dergisinde ise, Peyami Safa, Nazım Hikmet'e karşıt yazılar kaleme almıştır (Maral İşaşır, 2006: 10). 1927- 1928 yıllarında ise Ahmet Haşim Ikdam'da, Peyami Safa Cumhuriyet'te, Yakup Kadri Milliyet'te yazmıştır (Çıkla, 2009: 48-51). Sonraki yıllarda, Kültür Haftası, Insan, Ankara Halkevi'nin 'milli kültür dergisi' olarak nitelenen Ülkü, Atatürkçü sanat dergisi Yücel, Arkitekt, Güzel Sanatlar gibi dergiler kültür ve sanat konuları ile ilgilenmiştir (Sülün, 2009: 93-96).

Türk edebiyatındaki bir edebî hareket olan Garip ya da Birinci Yeni’nin temsilcileri Orhan Veli, Oktay Rıfat, Melih Cevdet ilk kez üçlü olarak 1936 yılında Varlık dergisinde görülmüştür. 'Garip' adlı kitapları ise 1941 yılında adı geçen şairlerin şiirleriyle çıkmıştır. Kitabın önsözü Orhan Veli tarafından kaleme alınmış olup burada mısracı zihniyete karşı çıkılmakta, vezin ve uyak reddedilmekte, edebî sanatlar istenmemekte, şiir için ayrı bir dilin varlığı kabul edilmemektedir. Bu şiirlerin ve hareketin başlangıcından yıllar sonra, Yaprak dergisi hareketin yayın organı olarak Orhan Veli'nin ölümüne kadar yayımlanmıştır (Sadıkoğlu, 2013: 4-9). 1941'de yayın hayatına başlayan Yürüyüşs dergisi, II. Dünya Savaş1 yıllarında Türkiye'de yaşanan baskılar karşısında özgürlük fikrini sanatla buluşturma mücadelesine girmiştir. Sait Faik, Orhan Kemal, Kemal Sülker, Burhan Arpad, Ömer Faruk Toprak, Rıfat Ilgaz, Samim Kocagöz, Kemal Bilbaşar'ın yazarları arasında yer aldığı derginin sosyalist fikirde olduğu söylenebilir. 1941 yılında yayın hayatına başlayan Yurt ve Dünya dergisinde ise Ludwig Van Beethoven, Bach, Charles Dickens, Rus tenkitçi Belinsky, Paul Muni, Şarlo, Max Reinhardt, Romain Rolland, Geza Gardonyi ve Erksine Caldwel gibi çeşitli alanlardaki sanatçıların öykülerine ve eserlerine yer verilmiştir. 1945 'te yayın hayatına başlayan Ant dergisi de sosyalist sanat görüşünü benimsemiştir. Behice Boran ve İlhan Berk' in yazarlarından olduğu dergide Faşizme ve Nazizm'e karş1 çıkan şiirler yer almıştır (Dinçer, 2008: 214-224). 1950'li yıllarda da gazetelerin birçoğu sanat ve edebiyat sayfaları düzenlemişlerdir. Örneğin, Pazar Postası edebiyata da çokça yer ayırmıştır (Çıkla, 2009: 48-51). Sosyalist görüşlerin yanı sıra, İslamcı ya da Türkçü görüssler de dergiler aracılığıyla aktarılmıştır.

İslamcı bir Türklük anlayışını benimseyen ve İslam dinin güzel sanatlar ve farklı konular hakkındaki görüşlerinin Büyük Doğu ideolojisi ile hayat bulacağına inanan Necip Fazıl Kısakürek (1947: 2), Ăgaç dergisinin ardından, 1943 yılında fikrî, edebî, siyasî ve dinî içerikli Büyük Doğu dergisini çıkarmıştır. Dergide şiir, öykü, eleştiri, deneme ve günlük gibi türlerdeki metinler de yer almıştır (Sadıkoğlu, 2013: 10). Fikirlerin aktarımının aracı yalnızca edebiyat olmamıştır. Resim ve görsel sanatlar da, fikirlerin temsilcisi olmuştur. Bu doğrultuda, sanat basını da bu fikirleri aktaran araç olmuştur. Örneğin, hem bir gazeteci hem de bir ressam olan Elif Naci'nin yazıları 1950'li yıllarda 
Türk Yurdu dergisinde yayımlanmıştır. Bu dergideki yazılarında Naci, Türkiye'deki sergilerin batılılaşmayı temsil ettiğinden, oysa Türkiye'deki sanatın yerel nitelikleri olması gerektiğinden bahsetmiştir ve Türk resminin ve Türk sanatının Alplerin ötesinde değil, Torosların eteklerinde olması gerektiğini savunmuştur (Sağ, 2011). Çağdaş Türk resminde yerel unsurları kullanan ressamlar arasında Turgut Zaim, Bedri Rahmi Eyüboğlu, Nurullah Berk, Zeki Faik İzer, Abidin Dino, Yüksel Arslan, Erol Akyavaş, Ergin İnan, S. Saim Tekcan, Devrim Erbil gibi sanatçılar da vardır. Bu sanatçıların eserlerinde geleneğe bağlı çağdaş Türk resmi kurma çabaları görünürdür (Bayramoğlu, 2013: 5). Örneğin, Bedri Rahmi Eyüboğlu resimlerinde batının sanat akımları ile geleneksel motifleri bir arada kullanır. 'Horon' ve 'Ebabil Kuşu' adlı resimlerinde bu durumu görmek mümkündür. Eyüboğlu'nun hem resimleri, hem şiirleri, hem de yazıları gazetelerde ve Ses ve Varlık gibi dergilerde yayımlanmıştır.

1960’lı yıllarda dönemin şairleri dergiler çıkararak edebiyat alanına katkı sağlamışlardır. Örneğin, 1960’lı yıllarda Cemal Süreya Papirüs dergisini, Sezai Karakoç ise Diriliş̧ dergisini çıkarmaya başlamıştır (And1, 1998: 8).1960'lı yıllara yayımlanan Hayat dergisinde de (1962: sayı 46) sanat hakkında yazılar mevcuttur. 1962 yılında yayımlanan 46. Sayısında, Richard Strauss'un operasindan, Champs-Elysees tiyatrosundan, Igor Stravinski'nin Rusya' da verdiği konserlerinden, yeni çıkan plaklardan ve ideal sanat anlayışından bahsedilmektedir. Hayat Dergisi ile birlikte yayımlanan Tarih Gazetesi'nde (1962: sayı 46: 183) ise, üç Fransız roman yazarı Stendhal, Chateaubriand ve Balzac'tan, Paganini ve Chopin'den, fotoğrafçı Louis Daguerre'den bahsedilmektedir. 1969 yılında yayın hayatına başlayan Edebiyat dergisinin çıkış amacı ise şu şekilde tanımlanmıştır: "Edebiyat dergisiyle, yurdumuzda, yerli, yeni bir edebiyatın gelişmesine, boy atmasına çalışıyoruz. Çıkışımızın amacı budur. Yurttaşlarımızı silkerek, sarsarak, uyandırarak, onlarla birlikte, düşünce düşmanlarına karşı koyacağız. Yerli edebiyatın, İslâm edebiyatının bir kurtuluş savaşı olacaktır bu" (Sadıkoğlu, 2013: 17-18). Bu dergi, İslam ve edebiyatın bir aradalığının örneklerindendir.

1970'li yıllarda yayın hayatına başlayan Sanat Çevresi ve Milliyet Sanat dergilerinde çeşitli sanat dallarına yer verilmiştir (Özaltın, 2016: 77-80). Milliyet Sanat dergisinin kurucularından Zeynep Oral (2006: 52), derginin çıkış amacının sanat haberciliği yapmak, sadece Türkiye'de değil dünyadaki önemli sanat olaylarına yer vermek, çağdaş evrensel kültürün çok yönlülüğünden pay almak ve ülkenin her köşesinde sanatsal ve kültürel oluşumları izleyerek yerel kültürlerin evrenselliğini vurgulamak olduğunu belirtmiştir. Sanat Çevresi dergisi ise sayfalarında sergilere, sanatçılara ve eserlerine yer vermiştir. Örneğin, bir sayısında (1992: 170) ressam Osman Hamdi Bey, Paris’te 19. Fiac Uluslararası Çağdaş Sanat Fuarı, Galeri Lebriz'de Hamit Görele Sergisi ve Ressam Metin Gönül konu edilmiştir.

Nur Koçak ve Tomur Atagök gibi sanatçılar 1980'li yılların getireceği derin değişimin ilk etkilerini yakından hissetmiş, çalışmalarını tüketim kültürüne paralel olarak kadın imgesi üzerinden ele almaya başlamışlardır. Batılı kültürün takip edilmesinde, dönemin birincil kaynağı olan basın, tüm bu sanatçıların konu olarak faydalandığı, çalışmalarına malzeme edindikleri bir mecra halini almıştır. Kolaj gibi dönemin geçerli plastik teknikleri, basını bir bilgi ve esin kaynağı olmaktan öte, çalışmaların malzemesi 
haline getirmiştir (Sağdıç May, 2015: 140). 2000'li yıllardan itibaren dijital ortamlar ile birlikte, Türkiye'de de sanat ve sanatçılar da dijital ortamlara kaysa da, günümüze kadar sanat dergileri varlıklarını sürdürmüşlerdir. Örneğin, günümüzde yayımlanmakta olan Sanat Dünyamız dergisi resim ve güzel sanatlar ile ilgilenmektedir, Milliyet Sanat dergisi ise dijital ortamda varlığını sürdürmektedir.

\section{Sonuç}

Sanat, insanlığın ilk çağlarından itibaren, şu anki anlamıyla olmasa da mevcut olmuştur. Sanat basını hakkında şimdiden başlayarak geçmişe uzanan bir inceleme yaptığımızda, hem dünyada kendini gösteren, hem de Osmanlı'dan Türkiye'ye uzanan sanat basınının, 17. Yüzyıldan itibaren sanatın aktarıcısı, pazarlayıcısı, yaratıcısı, hatta sanatın kendisi olarak farklı roller üstlendiğini görürüz. Ayrıca sanat basını, bir yandan mevcut düzeni pekiştirmeye yarayan bir araç, bir yandan da mevcut düzeni eleştiren bir başkaldırı olmuştur. Bu durum da sanat basınının iç çelişkilerinden biridir. Ekonomipolitik yapıda dönüşümler gerçekleştikçe sanat değişmiş, sanat değiştikçe basın da hem içerik, hem biçim, hem de oynadığı rol anlamında değişmiştir. Aydınlanma ve sanayileşme dönemi ile birlikte, sanat dini içeriklerden uzaklaşarak sıradan insanların ilgilerine ve doğaya yönelmiştir. İnsanın özne olarak var olduğu bu dönemde, insanlar memnuniyetsizliklerini de dile getirebilir olmuştur. Memnuniyetsizlikleri dile getirmenin yolu, isyan ve şiddet değil edebiyat ve sanat haline gelmiştir. Basın sanatı ise edebiyat ve sanat ile aktarılmak isteneni izleyiciye ulaştıran bir rol oynamıştır.

Fransız Devrimi, 1848 Devrimleri, Büyük Buhran, I. Dünya Savaşı, II. Dünya savaş1 gibi hem ekonomik hem de politik temelli olaylar, sanat basınını etkilemiştir. Pek çok alanda özgürlük arayışının ortaya çıktığı 19. Yüzyılda dergiler ve gazeteler de bu arayışın bir parçası haline gelmiştir. Örneğin, İngiltere'deki The Germ dergisi, Almanya'daki Propyläen dergisi, Osmanlı'daki Servet-i Fünun dergisi belli fikirlerin bir araya gelmesi için alan olmuştur. Ayrıca kimi zaman, basın sanat alanında belli ekolleri yaratmıştır. Bu duruma örnek olarak Servet-i Fünun dergisi verilebilir. Dünyanın geri kalanında yaşanan özgürlük arayışları, Tanzimat döneminde Osmanlı'da da mevcut olmuştur. Tasvir-i Efkâr'da şiir ve diğer edebi içeriklerin yayımlanmasıyla, edebiyat belli bir sınıfın ilgisi olmaktan çıkarak halkın ilgisi olmaya başlamıştır. Özgürlük arayışlarının bir uzantısı olarak kadınlar sanat alanında daha görünür hale gelmeye başlamıştır. Amerika'da Susan B. Anthony, Osmanlı'da Fitnat Hanım, Leyla Saz gibi isimler bu alanın öncülerinden olmuşlardır. Buna karşın bu dönemde, toplumsal hayata katılımın belli bir zümreye ait kadınlar için daha mümkün olduğu söylenebilir.

Savaş dönemlerinde, sanat ve edebiyat basını hem bir propaganda aracı olarak kullanılmıştır, hem de savaş karşıtı görüşleri yansıtmıştır. Ayrıca, bu dönemlerde yeni sanat akımları ortaya çıkmıştır. Dada ya da sürrealizm gibi akımlar, hem mevcut toplumsal düzene hem de mevcut sanat kalıplarına karş1 yeni anlayışlar öne sürmüşlerdir. Osmanlı'da ise savaş döneminde 1914 Kuşağı, sanat anlayışını değiştirmiştir. Yalnızca savaş dönemlerinde değil, hemen her dönemde sanat basını politik görüşlerin bir aktarıcısı olmuştur. Nazi sanat anlayışında klasik orana sahip, soluk benizli bedenler betimlenirken, 
komünist devletlerde işçi ve köylülerin idealize edildiği, liderlerin kült kişilikler olarak betimlendiği biçimler kullanılmıştır. Türkiye'de ise, Yürüyüş, Ant ve Papirüs gibi dergiler sol görüşleri yansıtırken, Büyük Doğu, Diriliş ve Türk Yurdu gibi dergiler ise milliyetçi görüşleri yansıtmıştır.

Yirminci yüzyılda yeni iletişim olanakları ile şairler ve diğer sanatçılar, dünyanın farklı yerlerinde tanınır hale gelmiştir. Sanat ve sanatçı, var olabilmek için basına, sanat basını ise varlığını sürdürebilmek için sanatçıların desteğine ihtiyaç duymuştur. Ayrıca bu yıllar sanatın teknoloji ile buluşmasına tanık olmuştur. Dergilerin iki boyutlu yapısı aşılmaya başlanırken, bir yandan da teknoloji, sanatın çoğaltılmasına neden olmuş, çoğaltılma ise sanatı içeriksizleştirmiş ve anlamsızlaştırmıştır. Dahası, dergi ve gazetelerin sayfaları sanat haline gelmiştir. Picasso gazete sayfalarını eserlerine yerleştirirken, basılı bir sayfanın maddeselliğini ve geçiciliğini yansıtmak için Aubertin'in dergi sayfasına üç kibrit yapıştırarak kibritleri yakması sanat eserine dönüşmüştür. Kapitalist piyasayı hiç olmadığı kadar güçlendiren, Pop Sanat gibi akımlar ise galerilerde değil sanat dergileri ile izleyici ile buluşur hale gelmiştir. Sanat olarak kabul edilen ürünler artık, galerilerde kendilerine yer bulamayacak bir biçim alırken, eskiden sanat olarak kabul edilen üretimlerin bu çağdaki üretimleri ise sanat olarak kabul görmez hale gelmiştir. 1970'lerden sonra ise dijital teknolojilerin hızla gelişimi ile birlikte, edebiyat ve sanat basını büyük ölçüde dijital ortama kaymıştır ve hem biçim, hem içerik, hem de anlam dönüşmüştür. 2000'li yıllardan itibaren ise, dijital teknolojiler sanatın dijital etkileşimine zemin oluşturmuştur. Başka bir ifadeyle, teknoloji geliştikçe sanatın anlamı da aktarılma biçimi de değişmiştir ve değişmeye devam edecektir.

\section{Kaynaklar}

Adorno, T. W., \& Horkheimer, M. (1944/2010). Aydınlanmanın diyalektiği. Çev. Nihat Ülner-Elif Öztarhan Karadoğan, İstanbul: Kabalcı.

Akdik, H. M. (2018). Modern Türk Edebiyatında Tabiat Algısl: Servet-İ Fünun Dönemi (1896-1901), Ege Üniversitesi Sosyal Bilimler Enstitüsü Türk Dili ve Edebiyatı Anabilim Dalı Doktora Tezi.

Akyüz, K. (1995). Modern Türk Edebiyatının Ana Çizgileri (1860-1923), İstanbul: İnkılâp Yayınevi.

Allen, G. (2005). Against Criticism: The Artist Interview in Avalanche Magazine, 1970-76. Art journal, 64(3), 50-61.

Allen, G. (2011). Artists'magazines: an alternative space for art. MIT Press.

Andı, M. F. (1998). İstanbul'a İki Bakış: Sezai Karakoç ve Cemal Süreya'nın Şiirlerinde İstanbul, İlmi Araştırmalar 6. 7-34.

Apaydın, D., \& Özakman, İ. (2019). Erken Cumhuriyet Döneminde Kısa Ömürlü Edebiyat Dergileri. Akademik Dil ve Edebiyat Dergisi, 3(1), 14-30.

Artforum

https://www.artforum.com/news/john-

baldessari-1931-2020-81811 Erişim tarihi: 16.05.2020 
Atatürk, M. K. (1997). Atatürk'ün Söylev ve Demeçleri, Ankara: Atatürk Araştırma Merkezi, C. II.

Atay, O. (2019). Tutunamayanlar. İstanbul: İletişim yayınları.

Ayaz, B. (2016). Geç kapitalizm: Medya ve sanatta içeriğin metalaşması ve anlamsızlaşması. Abant Kültürel Araştırmalar Dergisi, 1(1), 119-128.

Ayaz, B. (2017). The New Ottomans Press And The Spirit of The Age. Türkiye Sosyal Araştırmalar Dergisi, 21 (3) , 625-645.

Baldick, C. (2015). "For All We Have and Are". The Literary Encyclopedia, https:// www.litencyc.com/php/sworks.php?rec=true \&UID=35613, Erişim tarihi: 26.05.2020.

Ballmer, A. (2011). Avalanche Magazine: In the words of the artist. Art Documentation: Journal of the Art Libraries Society of North America, 30(1), 21-26.

Bayramoğlu, M. (2013). 20. Yüzyıl Türk Resim Sanatında Geleneksel Türk Sanat Örneklerinin Etkisi. Kalemişi, 1 (2), s.1-40.

Bektaş, D. (1992). Çă̆daş Grafik Tasarımın Gelişimi, İstanbul: Yap1 Kredi Yayınları.

Benjamin, W. (1935/1993). Mekanik Yeniden Üretim Çağında Sanat Eseri. Çev.: H. Hünler, Edebiyat \& Eleştiri, 2(3), 77-97.

Berger, J. (2015/2018). Portreler, Sanatçılar üzerine yazılar. Çev: Beril Eyüboğlu. İstanbul: Metis Yayınları.

Berkes, N. (2004). Türkiye'de Çağdaşlaşma. İstanbul: Yapı Kredi Yayınları.

Cardiff Üniversitesi Özel Koleksiyon ve Arşivleri, https://www.cardiff.ac.uk/ special-collections/subject-guides/illustrated-sources/art-and-architecture, Erişim tarihi: 09.05.2020

Clarke, M. (2010). Critical mediators: locating the art press. Visual Resources, 26(3), 226-241

Çeken, B., Akengin, G., \& Arslan, A. A. (2017). Sanatsal Bir Başkaldırı Olarak Dada. Akdeniz Sanat Dergisi, 10(20), 45-53.

Çeri B. \& Birinci, A. (2014). İzzet Ziya Edebiyatı Tuvalle Buluşturan Ressam. İstanbul. Kapı Yayınları.

Çı1kla, S. (2009). Tanzimat'tan Günümüze Gazete-Edebiyat İlişkisi. Türkbilig, 18, 34- 63.

Danto, A. C. (1997/2014). Sanatın Sonundan Sonra. Çev: Zeynep Demirsü. İstanbul: Ayrıntı Yayınları.

Der Weduwen, A. (2017). Dutch and Flemish Newspapers of the Seventeenth Century, 1618-1700 (2 Vols.). Brill.

Dinçer, H. (2008). II Dünya Savaş Yıllarında Türkiye'de Bir Dergi: Yurt ve Dünya. Atatürk Yolu Dergisi, 11(42), 193-230. 
Dirin, İ. (2009). Kültür - Sanat - Edebiyat - Tiyatro Musiki ve Folklor Dergileri (1929-1990). Yeni Türk Edebiyatı Araştırmaları.

Doğan, S. (2012). Tanzimat'tan Cumhuriyet'e Aydın Kadınlar; Şair ve Yazarlar. İstanbul: Akademik Kitaplar.

Dorleac, L., Dorléac, L. B., \& Guilbaut, S. (2008). Art of the Defeat: France 19401944. Getty Publications.

Drucker, J. (1994). The visible word: experimental typography and modern art, 1909-1923. University of Chicago Press.

Fitzgerald, M. C. (1996). Making modernism: Picasso and the creation of the market for twentieth-century art. Univ of California Press.

Gageldonk, M. V. (2010). Multimedia İn The Pre-Digital Age:'Aspen Magazine'(1965-1971) And The Digital Magazine Revolution.

Gezer, Ö. (2017). Sanat siyaset ilişkisi: propaganda ve protesto. Idil Sanat ve Dil Dergisi, 6(39), 3091-3110.

Goddard, L. (2006). Mallarmé, Picasso and the Aesthetic of the Newspaper. Word \& Image, 22(4), 293-303.

Gough, H. (2016). The newspaper press in the French Revolution. Routledge.

Green, B. (2009). The Feminist Periodical Press: Women, Periodical Studies, and Modernity. Literature Compass, 6(1), 191-205.

Grover, S.R. (1973). "The World of Art Movement in Russia" Russian Review, 32 (1): $28-42$.

Gülaçtı, İ. E. (2017). Osmanlı Resim Sanatı ve Propaganda İlişkisi: Padişah Resimleri ve Şişli Atölyesi. Yıldız Journal of Art and Design, 4(1), 29-65.

Günay, E. (2011). Nuri İyem ve Neșet Günal'ın Türk Resim Sanatı'ndaki yeri (Doctoral dissertation, Mehmet Akif Ersoy Üniversitesi Sosyal Bilimler Enstitüsü).

Habermas, J. (1962/1997). Kamusallığın Yapısal Dönüşümü. Çev: Tanıl Bora \& Mithat Sancar. İstanbul: İletişim Yayınları.

Hayat (1962). Sayı: 46.

Hayot, E. R. (2009). Chinese Dreams: Pound, Brecht, Tel Quel. University of Michigan Press.

Hothi, A. (2012). Aspen Magazine: 1965-71. Art Monthly, (362), 33.

İskit, S. (1937), Hususî İlk Türkçe Gazetemiz Tercüman-ı Ahval ve Agah Efendi, Ankara: Ulus Basımevi. Gruyter.

Kauppi, N. (2013). The making of an avant-garde: Tel Quel (Vol. 113). Walter de 
Kayıhan, Ç. (2010). Creating World of Aesthetics: Dante Gabriel Rossetti's Reaction to the Dominant Victorian Culture. Hacettepe Üniversitesi Sosyal Bilimler Enstitüsü İngiliz Dili ve Edebiyatı Anabilim Dalı, İngiliz Kültür Araştırmaları Yüksek Lisans Tezi.

Keser, İ., \& Keser, N. (2015). Kadın Tarihi için Bir Anıt: Akşam Yemeği Partisi. Uluslararası Sosyal Bilimler Dergisi International Journal of Social Sciences, 137.

Keskin, C. (2014). I. Dünya Savaşı ve Sonrası Türkiye'de KültürSanat Ortamı ve Türk Resmi. Gazi Akademik Bakış, (14), 263-179.

Ketner II, J. D. (2017). Witness to Phenomenon: Group ZERO and the Development of New Media in Postwar European Art. Bloomsbury Publishing USA.

Kılıç, N. (2015). Osmanlı Kadın Dergilerine Bir Örnek: Mürüvvet. Itobiad: Journal of the Human \& Social Science Researches, 4(3).

Kısakürek, N. F. (1947). "İnanıyoruz”, Büyük Doğu, Cilt 3, Sayı 60 (25 Nisan 1947), s. 2.

Kirkpatric, R. (2003). "Pacific Rim Cultures and Newspapers". (Ed.). Copeland, D. A. ve

Kolokytha, C. (2013). The art press and visual culture in paris during the great depression: Cahiers d'art, Minotaure, and Verve. Visual Resources, 29(3), 184-215.

Köroğlu, E. (2004). Türk edebiyatı ve Birinci Dünya Savaşı (1914-1918): Propagandadan millî kimlik inşasına (Vol. 164). İstanbul: İletişim Yayınları.

Kula, O. B. (2013). Marx, Benjamin, Adorno Sanat ve Edebiyat. İstanbul: Türkiye İş Bankası Yayınları.

Maral İ. C. (2006). Resimli Ay Dergisi’nde (1928-1930) Edebi ve Fikrî Gelişmeler, Gazi Üniversitesi Sosyal Bilimler Enstitüsü Türk Dili ve Edebiyatı Ana Bilim Dalı Yeni Türk Edebiyatı Bilim Dalı Yüksek Lisans Tezi.

Mardin, Ş. (2015). Yeni Osmanlı düşüncesinin doğuşu. İstanbul: İletişim Yayınları.

Martín, S. E. (2003). The function of newspapers in society: A global perspective. Ss. 61-79. Greenwood Publishing Group.

Marx, K., \& Engels, F. (1848/1967). The Communist Manifesto. Çev: Samuel Moore. London: Penguin.

Mott, F. L. (2002). A History of American Magazines, 1850-1865 (Vol. 2). Harvard University Press.

Ollman, B. (2011). Diyalektiğin Dansı, Marx’ın Yönetiminde Adımlar. İstanbul: Yordam Kitap.

Oral, Z. (2006). Meslek Yarast. İstanbul: Doğan Kitap.

Özakın, D. (2018). Art Nouveau Akımının Rus Sanat Dünyasında Yorumlanması: Rus Stili. Art-Sanat 9, 241-251. 
Özalp, F. (2011). Georgia O'Keeffe 'nin sanatında renk, ışıkve imge. Işı1k Üniversitesi Yüksek Lisans Tezi.

Özaltın, Z. (2016). Sanat Eleş̧irisi Kültürünün Türkiye'de Gelişimi 1880-1980, Yıldız Teknik Üniversitesi Sosyal Bilimler Enstitüsü Yüksek Lisans Tezi.

Özyiğit, H. (2017). Osmanlı'dan Cumhuriyet'e geçiş sürecinde basında resim eleştirisi. Pamukkale Üniversitesi Sosyal Bilimler Enstitüsü Dergisi, (27), 174-196.

Patterson, C. L. (2011). Art for the Middle Classes: America's Illustrated Magazines of the 1840s. Univ. Press of Mississippi.

Peckham, M. (2010). Victorian revolutionaries: Speculations on some heroes of a culture crisis. Transaction Publishers.

Polat, N. H. \& Yaygın E. Ö. (2019). "Musavver Hâle” Dergisi Üzerine Bir İnceleme, Tübar XLV, 173-198.

Pörschmann, D. “The Sun Is ZERO” Light and Color as Principles of Structural Order.

Raymond, J. (2005). The invention of the newspaper: English newsbooks, 16411649. Oxford University Press.

Ritsos, Y. (2002). Görülmemiş bir çiçek açma. İstanbul: Adam yayıncılık.

Rugh, W. A. (2003). "Arab Cultures and Newspapers". (Ed.). Copeland, D. A. ve Martín, S. E (2003). The function of newspapers in society: A global perspective. Ss. 1331. Greenwood Publishing Group.

Sadıkoğlu, İ. (2013). Modern Türk Edebiyatı içinde Nuri Pakdil'in edebiyat dergisinin yeri ve rolü. FSM Vakıf Üniversitesi Sosyal Bilimler Enstitüsü Türk Dili ve Edebiyatı Anabilim Dalı Yüksek Lisans Tezi.

Sağ, M. (2011). Türk Yurdu, Sayı 281. https://www.turkyurdu.com.tr/yazar-yazi. php?id=1370 Erişim tarihi: 26.05.2020

Sağdıç, M. D. (2015). 1980 Sonrası, Kadın Imgesinin Yazılı Medyada Kullanım Yöntemlerinin Türk Plastik Sanatına Etkileri. T.C. Doğuş Üniversitesi Sosyal Bilimler Enstitüsü Sanat ve Tasarım Fakültesi Plastik Sanatlar Yüksek Lisans Tezi.

Sanat Dünyamız (1992). Say1 170.

Sülün, E. N. (2009). Türkiye'de Popüler Kültür ve Medyada Sanat: Milliyet Sanat Dergisi Örneği, Hacettepe Üniversitesi Güzel Sanatlar Fakültesi Dergisi, Sanat Yazıları 18, ISSN 1300-6665, s. 93-113.

Tanpınar, A. H. (1997). 19. Asır Türk Edebiyatı Tarihi, İstanbul: Çağlayan Kitabevi.

Tarih Gazetesi (1962). Say1: 46, s.183.

Tonga, N. (2014). Cumhuriyet Ankarası'nın devraldığı edebî miras: Cumhuriyet Dönemi'ne kadarAnkara'daki edebiyat hayatı ve edebiyat mahfilleri. Ankara Araştırmaları Dergisi, 2(2), 184-202. 